\title{
Derived Intervention Levels for Tritium Based on Food and Drug Administration Methodology
}

by

A. Blanchard

Westinghouse Savannah River Company

Savannah River Site

Aiken, South Carolina 29808

B. K. Tharakan

WSMS

This paper was prepared in connection with work done under the above contract number with the U.S. Department of Energy. By acceptance of this paper, the publisher and/or recipient acknowledges the U. S. Government's right to retain a nonexclusive, royalty-free license in and to any copyright covering this paper, along with the right to reproduce and to authorize others to reproduce all or part of the copyrighted paper. 


\section{DISCLAIMER}

This report was prepared as an account of work sponsored by an agency of the United States Government. Neither the United States Government nor any agency thereof, nor any of their employees, makes any warranty, express or implied, or assumes any legal liability or responsibility for the accuracy, completeness, or usefulness of any information, apparatus, product, or process disclosed, or represents that its use would not infringe privately owned rights. Reference herein to any specific commercial product, process, or service by trade name, trademark, manufacturer, or otherwise does not necessarily constitute or imply its endorsement, recommendation, or favoring by the United States Government or any agency thereof. The views and opinions of authors expressed herein do.not necessarily state or reflect those of the United States Government or any agency thereof.

This report has been reproduced directly from the best available copy.

Available to DOE and DOE contractors from the Office of Scientific and Technical Information, P. O. Box 62, Oak Ridge, TN 37831; prices available from (423) 576-8401.

Available to the public from the National Technical Information Service, U. S. Department of Commerce, 5285.Port Royal Road, Springfield, VA 22161. 


\section{DISCLAIMER}

\section{Portions of this document may be illegible in electronic image products. Images are produced from the best available original document.}




\title{
Derived Intervention Levels for Tritium based on Food and Drug Administration Methodology (U)
}

\author{
Binesh K. Tharakan
}

November 1998

Westinghouse Savannah River Company Project Engineering \& Construction Division Aiken, SC 29808

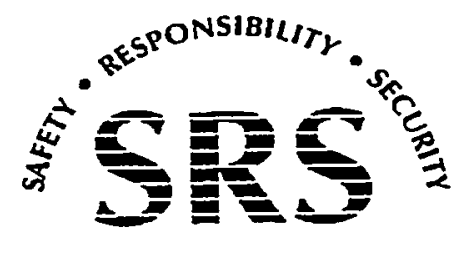

PREPARED FOR THE U.S. DEPARTMENT OF ENERGY UNDER CONTRACT NO. DE-AC09-96SR18500 
Keywords: Tritium

Emergency Planning

Derived Intervention Level

Retention: Lifetime

\section{Derived Intervention Levels for Tritium based on Food and Drug Administration Methodology (U)}

November 1998

Classification

\section{UNCLASSIFIED}

DOES NOT CONTAIN

UNCLASSIFIED CONTROLLED

NUCLEAR INFORMÁTION

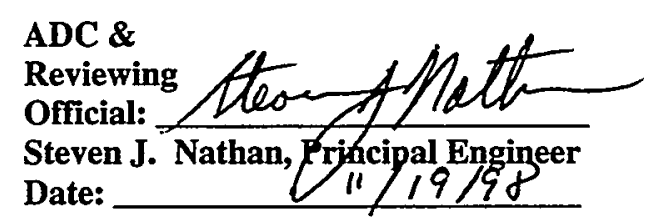

Westinghouse Savannah River Company Project Engineering \& Construction Division Aiken, SC 29808

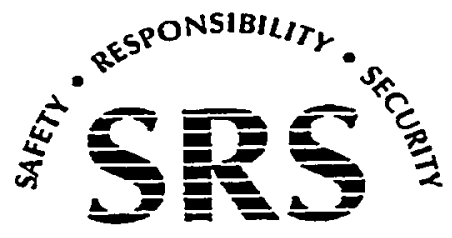


PROJECT: $\quad$ N/A

DOCUMENT:

TITLE:
WSRC-TR-98-00419

Derived Intervention Levels for Tritium based on Food and Drug Administration Methodology (U)

0

\section{AUTHOR/TECHNICAL REVIEWS:}

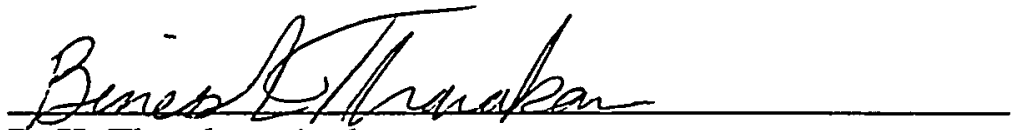

B. K. Tharakan, Author
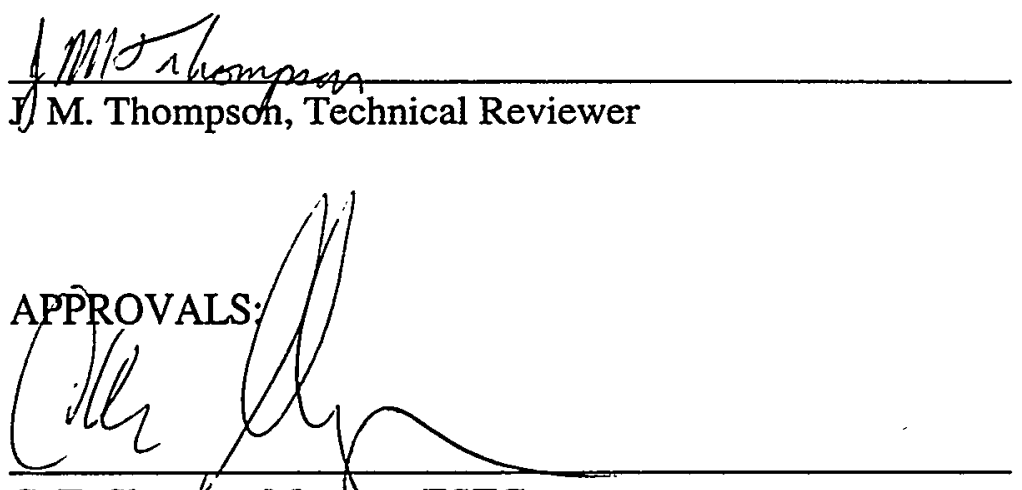

C. E. Shogren, Managger ESTG

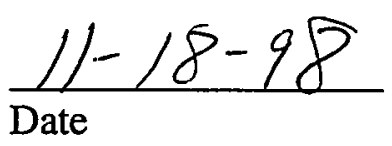

$\frac{11 / 19 / 98}{\text { Date }}$

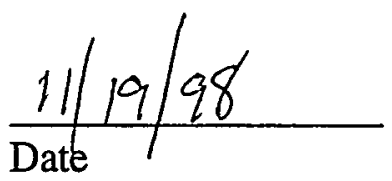




\section{Abstract}

In 1998, the FDA released its recommendations for age-dependent derived intervention levels for several radionuclides involved in nuclear accidents. One radionuclide that is not included in that document is tritium. Therefore an analysis is presented here to develop Derived Intervention Levels (DILs) for tritium in two forms: HTO and OBT. The most conservative DIL was chosen as the recommended DIL for tritium. This DIL is for OBT in the 1 year age group. The value of the DIL for tritium is $8.2 \times 10^{4} \mathrm{~Bq} \mathrm{~kg}^{-1}$. 


\section{TABLE OF CONTENTS}

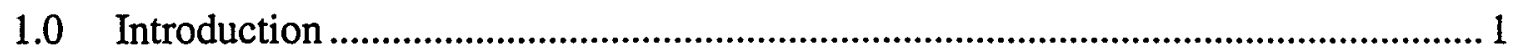

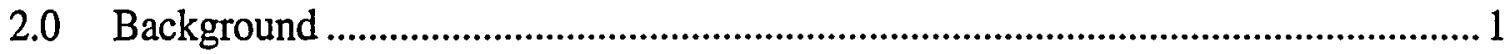

2.1 Protective Action Guides ........................................................................ 1

2.2 Derived Intervention Levels ......................................................................... 2

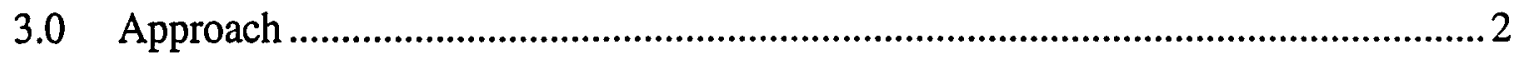

3.1 Protective Action Guides used in Tritium DIL Calculation ..............................2

3.2 Age Groups and Dose Coefficients (DCs) ........................................................ 3

3.3 Food Intake .................................................................................................. 3

3.4 Fractions of Food Intake Assumed to be Contaminated $(f)$.................................. 3

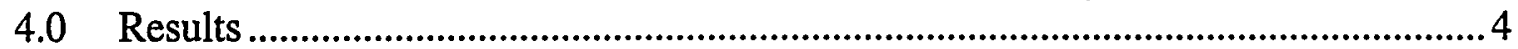

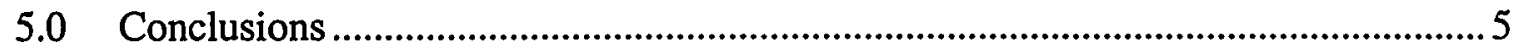

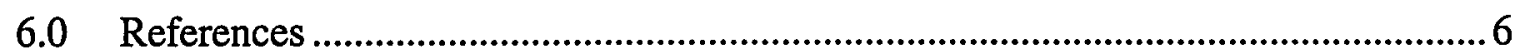


WSRC-TR-98-00419

Revision 0 Page iv

\section{LIST OF TABLES}

Table 4.1. Calculation of Derived Intervention Levels for Tritium....................... 4 


\subsection{Introduction}

Recommendations on accidental radioactive contamination of human food and animal feeds were issued in 1982 by the Food and Drug Administration (FDA). Since then, significant advancements related to emergency planning and dose assessment to humans has taken place. Therefore, updated recommendations on accidental radioactive contamination of human food and animal feeds were issued by the Food and Drug Administration in 1998 (FDA 1998). However, FDA 1998 did not provide any recommendations for the accidental contamination of human foods and animal feeds with tritium. This document intends to develop Derived Intervention Levels (DILs) for both tritiated water (HTO) and for Organically Bound Tritium (OBT). The data used to develop the DIL for tritium will be based on the FDA methodology described in its 1998 publication. The derivation of the DIL will use the most current data from the ICRP that is available at the time of this report.

\subsection{Background}

On 13 August 1998, the FDA issued their document on Accidental Radioactive Contamination of Human Food and Animal Feeds: Recommendations for State and Local Agencies. This document is intended to provide guidance and represents FDA thinking on the subject. The recommendations advise that health risk to the public be averted by limiting the radiation dose received as a result of consumption of accidentally contaminated food. This will be accomplished by: (1) setting limits, called Derived Intervention Levels (DILs) on the radionuclide activity concentration permitted in human food, and (2) taking protective actions to reduce the amount of contamination (FDA 1998).

It is not within the scope of this document to provide instructions for taking protective actions to reduce the amount of contamination. The FDA has established DILs for several radionuclides in its 1998 document. The objective of this report will be to establish a $\mathrm{DIL}$ for tritiated water and organically bound tritium using the same methodology as the FDA.

\subsection{Protective Action Guides}

In 1982, the FDA recommendations originally established two levels of Protective Action Guides (PAGs). PAGs were defined as " projected dose commitment values to individuals in the general population that warrant protective action following a release of radioactive material." The lower level, called the Preventive PAG, was a projected dose commitment of $0.005 \mathrm{~Sv}$ to the whole body, active bone marrow, or any other organ except the thyroid, or a projected dose commitment of $0.015 \mathrm{~Sv}$ to the thyroid. The Preventive PAG was associated with low-impact protective actions (e.g. placing dairy cows on stored feed). The upper level, called the Emergency PAG, was a projected dose commitment of $0.05 \mathrm{~Sv}$ to the whole body, active bone marrow, or any other organ except the thyroid, or a projected dose commitment of $0.150 \mathrm{~Sv}$ to the thyroid. The 
Emergency PAG was associated with higher-impact protective actions (e.g. diversion of fresh milk to cheese or milk powder).

In 1998, the FDA's current recommendations replace the Preventive and Emergency PAGs with one set of PAGs for the ingestion pathway. The PAGs are $0.005 \mathrm{~Sv}$ for committed effective dose equivalent or $0.05 \mathrm{~Sv}$ committed dose equivalent to an individual tissue or organ, whichever is more limiting.

\subsection{Derived Intervention Levels}

A DIL corresponds to the concentration in food present throughout the relevant period of time that, in the absence of any intervention, could lead to an individual receiving a radiation dose equal to the PAG. The basic equation for calculating the $\mathrm{DL}$ is given by:

$$
D I L(B q / k g)=\frac{P A G(S v)}{f \times \text { Foodlntake }(k g) \times D C(S v / B q)} \quad \text { Eq. } 1.0
$$

Where:

DC = Dose Coefficient; the radiation dose received per unit of activity ingested $(\mathrm{Sv} / \mathrm{Bq})$.

$f \quad=$ Fraction of food intake assumed to be contaminated.

Food Intake $\quad=$ Quantity of food consumed in an appropriate period of time (kg):

The DIL for tritium is selected based on current FDA methodology for deriving DILs, which provides a large margin of safety.

\subsection{Approach}

The approach taken to determine the DIL for tritium is the same as the approach taken for other radionuclides in FDA 1998. The recommended PAGs are $0.005 \mathrm{~Sv}$ committed effective dose equivalent, or $0.05 \mathrm{~Sv}$ committed dose equivalent to individual tissues and organs, whichever is more limiting. These PAGs are consistent with the consensus of international organizations on the levels of radiation dose below which ingestion pathway interventions are generally not appropriate.

\subsection{Protective Action Guides used in Tritium DIL Calculation}

For the case of tritium, the most limiting PAG will be the $0.005 \mathrm{~Sv}$ committed effective dose equivalent since tritium is so readily adsorbed throughout the body's organs and tissues. Therefore the dose coefficient will be the same for each organ or tissue as it is for the whole body. Only the 0.005 Sv PAG was considered when calculating the DILs for tritium, given in Table 4.1. 


\subsection{Age Groups and Dose Coefficients (DCs)}

The general population was divided into six age groups ranging from infants to adults and corresponding to the age groups in ICRP Publication 56 (ICRP 1989) for which ICRP has published DCs. The age groups are 3 months, 1 year, 5 years, 10 years, 15 years, and adult. The DIL was calculated for each age group and is listed in Table 4.1. The Dose Coefficients used for this calculation come from the more recent ICRP Publication 72 (ICRP 1995).

\subsection{Food Intake}

Food intake included all dietary components including tap water used for drinking, and is the overall quantity consumed in one year. Dietary intakes were derived from a 1984 EPA report which presented average daily food intake by age and gender (EPA 1984a, EPA 1984b). The EPA intakes were based on data from the 1977-1978 Nationwide Food Consumption Survey published by the U. S. Department of Agriculture (USDA 1982, USDA 1983). The Food Intake values were taken directly from FDA 1998, Table D-3.

\subsection{Fractions of Food Intake Assumed to be Contaminated $(f)$}

For food consumed by most members of the general public, ten percent of the dietary intakes was assumed to be contaminated. This assumption recognizes the ready availability of uncontaminated food from unaffected areas of the United States or through importation from other countries, and also that many factors could reduce or eliminate contamination of local food by the time it reaches the market.

Use of ten percent of the dietary intake as the portion contaminated was consistent with recommendations made by a Group of Experts to the Commission of the European Communities and by the Nuclear Energy Agency (NEA) of the Organization for Economic Cooperation and Development. The NEA noted that modification of this value would be appropriate if justified by detailed local findings (FDA 1998).

FDA applied an additional factor of three to account for the fact that sub-populations might be more dependent on local food supplies (FDA 1998). Therefore, during the immediate period after a nuclear accident, a value of 0.3 (i.e., thirty percent) is the fraction of food intake that the FDA recommends should be presumed to be contaminated. If, subsequently, there is convincing local information that the actual fraction of food intake that is contaminated $(f)$ is considerably higher or lower, there will be adequate time for State and local officials to determine whether to adjust the value of $f$ (and therefore adjust the value of the DILs) for the affected area.

For infants (i.e., age groups 3 months and 1 year) the diet consists of a high percentage of milk and the entire milk intake of some infants over a short period of time might come from supplies directly impacted by an accident. Therefore, $f$ was set equal to $1.0(100 \%)$ for the infant diet (see Table 4.1), consistent with FDA 1998. 


\subsection{Results}

Equation 1 was used to calculate the DIL using data listed in Table 4.1. Equation 1 is:

$$
D I L(B q / k g)=\frac{P A G(S v)}{f \times \text { FoodIntake }(k g) \times D C(S v / B q)}
$$

The results of the calculation show the DILs for each age group and for both forms of tritium.

Table 4.1 Calculation of Derived Intervention Levels (DILs) for Tritium

\begin{tabular}{|c|c|c|c|c|c|c|}
\hline HTO & 3 months & 1 year & 5 year & 10 year & 15 year & adult \\
\hline $\begin{array}{l}\text { DC (Sv/Bq) } \\
\text { f } \\
\text { PAG (Sv) } \\
\text { food intake }(\mathrm{kg})\end{array}$ & $\begin{array}{c}6.40 \times 10^{-11} \\
1 \\
0.005 \\
418\end{array}$ & $\begin{array}{c}4.80 \times 10^{-11} \\
1 \\
0.005 \\
506\end{array}$ & $\begin{array}{c}3.10 \times 10^{-11} \\
0.3 \\
0.005 \\
660\end{array}$ & $\begin{array}{c}2.30 \times 10^{-11} \\
0.3 \\
0.005 \\
779\end{array}$ & $\begin{array}{c}1.80 \times 10^{-11} \\
0.3 \\
0.005 \\
869\end{array}$ & $\begin{array}{c}1.80 \times 10^{-11} \\
0.3 \\
0.005 \\
943\end{array}$ \\
\hline$\overline{D I L}(B q / \mathbf{k g})$ & $1.9 \times 10^{5}$ & $2.1 \times 10^{5}$ & $8.2 \times 10^{5}$ & $9.3 \times 10^{5}$ & $1.1 \times 10^{6}$ & $9.8 \times 10^{5}$ \\
\hline OBT & 3 months & 1 year & 5 year & 10 year & 15 year & Adult \\
\hline $\begin{array}{l}\text { DC (Sv/Bq) } \\
f \\
\text { PAG (Sv) } \\
\text { food intake }(\mathrm{kg})\end{array}$ & $\begin{array}{c}1.20 \times 10^{-10} \\
1 \\
0.005 \\
418\end{array}$ & $\begin{array}{c}1.20 \times 10^{-10} \\
1 \\
0.005 \\
506\end{array}$ & $\begin{array}{c}7.30 \times 10^{-11} \\
0.3 \\
0.005 \\
660\end{array}$ & $\begin{array}{c}5.70 \times 10^{-11} \\
0.3 \\
0.005 \\
779\end{array}$ & $\begin{array}{c}4.20 \times 10^{-11} \\
0.3 \\
0.005 \\
869\end{array}$ & $\begin{array}{c}4.20 \times 10^{-1 i} \\
0.3 \\
0.005 \\
943\end{array}$ \\
\hline$\overline{\mathrm{DIL}}(\mathrm{Bq} / \mathrm{kg})$ & $1.0 \times 10^{5}$ & $8.2 \times 10^{4}$ & $3.5 \times 10^{5}$ & $3.8 \times 10^{5}$ & $4.6 \times 10^{5}$ & $4.2 \times 10^{5}$ \\
\hline
\end{tabular}




\subsection{Conclusions}

Derived Intervention Levels were developed for tritium in water (HTO) and organically bound tritium (OBT). The most limiting DIL for HTO is $1.9 \times 10^{5} \mathrm{~Bq} \mathrm{~kg}^{-1}$ in the 3 month age group. The most limiting DIL for OBT is $8.2 \times 10^{4} \mathrm{~Bq} \mathrm{~kg}^{-1}$ in the 1 year age group. Of these two, the recommended Derived Intervention Level for tritium would be $8.2 \times 10^{4}$ $\mathrm{Bq} \mathrm{kg}^{-1}$. Any quantity of tritium ingested greater than this $\mathrm{DIL}$ would exceed the PAG for tritium and result in an individual committed effective dose equivalent of greater than $0.005 \mathrm{~Sv}$. 


\subsection{References}

(EPA 1984a) Environmental Protection Agency. An Estimation of the Daily Food Intake Based on Data from the 1977-1978 USDA Nationwide Food Consumption Survey. Office of Radiation Programs, EPA 520/1-84015, Washington D.C.; 1984.

(EPA 1984b) Environmental Protection Agency. An Estimation of the Daily Average Food Intake by Age and Sex for Use in Assessing the Radionuclide Intake of Individuals in the General Population. Office of Radiation Programs, EPA 520/1-84-021, Washington, D. C.; 1984.

(FDA 1998) Food and Drug Administration. Accidental Radioactive Contamination of Human Foods and Animal Feeds: Recommendations for State and Local Agencies. U. S. Department of Health and Human Services, Food and Drug Administration, Center for Devices and Radiological Health, Rockville, MD.; August 13, 1998.

(ICRP 1989) International Commission on Radiological Protection. Age-dependent Doses to Members of the Public from Intake of Radionuclides: Part 1. Pergamon Press, Oxford, U.K.; ICRP Publication 56, Annals of the ICRP Vol. 20, No. 2; 1989.

(ICRP 1995) International Commission on Radiological Protection. Age-dependent Doses to Members of the Public from Intake of Radionuclides: Part 5 Compilation of Ingestion and Inhalation Dose Coefficients. Pergamon Press, Oxford, U.K.; ICRP Publication 72, 1995.

(USDA 1982) U. S. Department of Agriculture. Foods Commonly Eaten by Individuals: Amount Per Day and Per Eating Occasion. Human Nutrition Service, Home Economics Research Report No. 44, Washington, D. C.; March 1982.

(USDA 1983) U. S. Department of Agriculture. Food Intakes: Individuals in 49 States, Year 1977-1978. Human Nutrition Service, National Food Consumption Survey 1977-78, Report No. I-1, Washington, D. C.; August 1983. 